\title{
Inhibition of Gibberellin Biosynthesis by Geraniol Derivatives and 17-Nor-16-azakauranes ${ }^{\dagger}$
}

\author{
Kojiro $W_{A D A}$ \\ Department of Agricultural Chemistry, Nagoya University, Nagoya 464, Japan
}

Received October 20, 1977

\begin{abstract}
Four analogues of the intermediates of gibberellin biosynthesis, 1-geranylimidazole (V) and three 17-nor-16-azakauranes (VIII), (IX) and $(\mathrm{X})$ were found to inhibit gibberellin production of Gibberella fujikuroi by the procedure of bioassay which the author established. These compounds showed also growth retarding effects on rice seedlings.
\end{abstract}

Many researchers have recently focused their attention on the inhibitors of biologically active isoprenoid biosyntheses because these inhibitors are not only useful as a tool of the study on the biosynthetic pathways of isoprenoids, but also used as medicines or agricultural chemicals. ${ }^{1 \sim 31}$

The inhibitors of gibberellin biosynthesis have been used as plant growth retardants, and the typical plant growth retardants, AMO-1618 and phosphon $D$, were found to inhibit specifically the conversion of geranylgeranyl pyrophosphate (2) to copalyl pyrophosphate (3) by the kaurene synthetase purified from Marah macrocarpus." These quaternary ammonium or phosphonium salts are active primarily on plants among the Dicotyledonae, but they are effective on a few species in Monocotyledonae. ${ }^{5}$ ) These facts have stimulated the author to screen new inhibitors of gibberellin biosynthesis. The author now reports the biological activities, inhibition of gibberellin production and plant growth retarding effects of geraniol derivatives and azakauranes.

The biosynthetic pathway of gibberellins is as shown in Fig. $1^{6}$ ) and many analogues of the intermediates of isoprenoid biosyntheses have been used as the biosyntheses inhibitors. ${ }^{1}$ Thus, the author prepared the analogues of geranylgeranyl pyrophosphate (2) and kaurene (4) as the candidate compounds of gibberellin biosynthesis inhibitors. The analogues of

\footnotetext{
+ Studies on the Inhibitors of Gibberellin Biosynthesis. Part I.
}

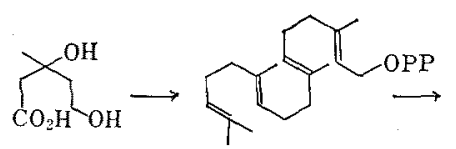

(1)

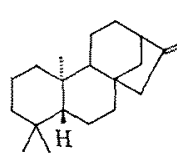

(4)

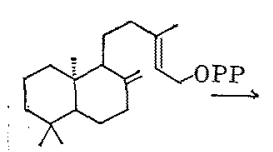

(3)
FIG. 1. Biosynthetic Pathway of Gibberellins.

geranylgeranyl pyrophosphate were synthesized by the alkylation of the phenols or amines with geranylbromide in the presence of sodium hydride in DMF. The geraniol derivatives thus prepared are compounds I to VII and the structures were confirmed on the basis of the IR, UV, NMR and mass spectra. The second series of the candidate compounds are 17-nor16-azakauranes, VIII, IX and X, which were obtained by the reductive amination ${ }^{7}$ of 17 nor-kauran-16-one derived from (-)-kaurene.

The gibberellin biosynthetic system in the mycelium of Gibberella fujikuroi was used for the bioassay of gibberellin biosynthesis inhibitors. The mycelium having the enzyme system for gibberellin biosynthesis was obtained by the cultivation of $G$. fujikuroi in the potato-glucose medium for 3 days. The wet mycelium which was washed with $0.5 \% \mathrm{NaCl}$ was shown not to contain any gibberellins by the GC analysis of the methyl esters of its solvent extract. Inhibition of gibberellin production was measured by the GC analysis of 
<smiles></smiles>

(I)<smiles>COc1cccc2c1OCC1=C2CC=C1</smiles>

(II)

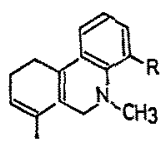

(III), (N)<smiles>CC1=CCCC(C)=C1CC1C2=CC1C2</smiles>

(v)

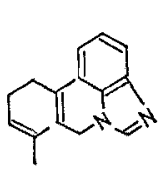

(VI)<smiles></smiles>

(VII)<smiles></smiles>

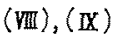<smiles>CC1CCC23CCC1(C)CCC21CCCC(C)(C)C13</smiles>

(X)

(I), O-geranylsesamol; (II), methyl o-geranyloxybenzoate; (III), R=H, N-geranyl, N-methylaniline; (IV), $\mathrm{R}=\mathrm{CO}_{2} \mathrm{Me}$, methyl $\mathrm{N}$-geranyl, $\mathrm{N}$-methylanthraanilate; (V), 1-geranylimidazole;

(VI), 1-geranylbenzimidazole; (VII), methyl $p$-geranyloxybenzoate; (VIII), 17-nor-16-methylaminokaurane; (IX), 17-nor-16-dimethylaminokaurane; (X), 17-nor-16-dimethylaminokaurane methoiodide.

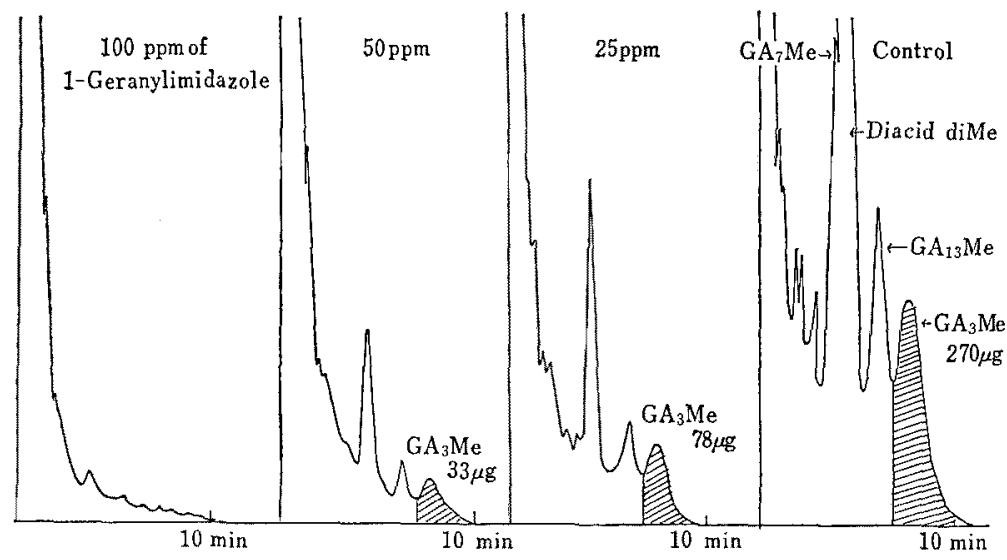

Fig. 2. GC of Methylated Acids Produced in Mycelium Suspensions.

the methyl esters of the acidic metabolites which were produced in the mycelium suspensions containing candidate compounds. The gas chromatogram of the methyl esters of the acidic metabolites produced in control suspension was as shown in Fig. 2 and the major peaks were assigned to $\mathrm{GA}_{7}$, diacid, $\mathrm{GA}_{13}$ and $\mathrm{GA}_{3}$ using $\mathrm{GC}-\mathrm{MS}$ analysis. The amount of $\mathrm{GA}_{3}$ produced in the control was $270 \mu \mathrm{g}$.

When $100 \mathrm{ppm}$ of compound V, 1-geranylimidazole, was added to the mycelium suspension, the production of gibberellins was completely inhibited as shown in Fig. 2. In the case of 50 or $25 \mathrm{ppm}$ of $\mathrm{V}$, the amounts of $\mathrm{GA}_{3}$ decreased to 33 or $78 \mu \mathrm{g}$, respectively.

Table I represents the effects of geraniol
Table I. Inhibition of Gibberellin Production Each value represents the percent inhibition.

\begin{tabular}{rrrrrr}
\hline Sample & \multicolumn{5}{c}{ Concentration (ppm) } \\
& 500 & 200 & 100 & 50 & 25 \\
\hline I & 14 & - & - & - & - \\
II & 20 & - & - & - & - \\
III & 44 & 17 & 27 & 21 & - \\
IV & 48 & 48 & 46 & 45 & - \\
V & 100 & 100 & 97 & 88 & 71 \\
VI & 100 & 100 & 79 & 46 & 33 \\
VII & 27 & - & - & - & - \\
VIII & 100 & 100 & 100 & 36 & 20 \\
IX & 100 & 100 & 78 & 39 & 23 \\
X & 100 & 100 & 82 & 54 & 53 \\
\hline
\end{tabular}

derivatives and 17-nor-16-azakauranes on the gibberellin production of $G$. fujikuroi. 1Geranylimidazole (V) showed about 100\% 
inhibition at over $100 \mathrm{ppm}$ and 1-geranylbenzimidazole (VI) also showed 100\% inhibition at over $200 \mathrm{ppm}$, but other geraniol derivatives showed $48 \%$ inhibition at the most even in a high concentration of $500 \mathrm{ppm}$.

17-Nor-16-azakauranes, VIII, IX and $\mathrm{X}$ showed about 80 to $100 \%$ inhibition at $100 \mathrm{ppm}$. 1-Geranylimidazole (V) and the methoiodide (X) did not inhibit the mycelium growth of G. fujikuroi in liquid potato-glucose medium at the concentrations of below $100 \mathrm{ppm}$, whereas the compounds, VIII and IX, inhibited the mycelium growth at over $50 \mathrm{ppm}$. These facts suggest that $\mathrm{V}$ and $\mathrm{X}$ inhibit gibberellin biosynthesis without significant effects on the other metabolisms of G. fujikuroi at low concentrations of below 100 ppm, but VIII and IX are not specific inhibitors of gibberellin biosynthesis.

On the next, the plant growth retarding effects of the above derivatives except VII were examined using a standard rice seedling test described in EXPERIMENTAL. Table II shows

Table II. Effect of Geraniol Derivatives AND 17-Nor-16-AZaKauranes ON THE SECOND Leaf Sheath and Root Growth of Rice SEedlings (Normal cV., Kinmaze)

A denotes the relative growth of second leaf sheath (control: 100), B denotes the relative growth of root (control: 100).

\begin{tabular}{rrrrrrr}
\hline Sample & \multicolumn{6}{c}{ Concentration (ppm) } \\
& \multicolumn{2}{c}{300} & \multicolumn{3}{c}{100} \\
\hline I & A & B & A & B & A & \multicolumn{1}{c}{ B } \\
II & 90 & 110 & 89 & 93 & 93 & 92 \\
III & 85 & 99 & 85 & 105 & 91 & 100 \\
IV & 78 & 120 & 84 & 126 & 87 & 117 \\
V & 93 & 163 & 87 & 127 & 90 & 132 \\
VI & 12 & 19 & 45 & 68 & 80 & 58 \\
VIII & 70 & 12 & 89 & 51 & 87 & 59 \\
IX & 0 & 0 & 34 & 0 & 74 & 6 \\
X & 0 & 0 & 22 & 0 & 78 & 9 \\
\hline
\end{tabular}

the effects of geraniol derivatives and 17-nor16-azakauranes on the second leaf sheath and root growth of rice seedlings. Only the compounds having the inhibitory activity on gibberellin biosynthesis showed growth retarding effects on the second leaf sheath of rice seedlings. 1-Geranylimidazole (V) showed $88 \%$ inhibition of the second leaf sheath at $300 \mathrm{ppm}$, but 1-geranylbenzimidazole (VI) only $30 \%$ inhibition at the same concentration.

On the other hand, 17-nor-16-azakauranes, VIII and IX, inhibited completely the shoot growth of rice seedlings at $300 \mathrm{ppm}$, and $X$ showed $62 \%$ inhibition of the second leaf sheath growth at the same concentration. The decisive difference in the plant growth retarding activities of compound $\mathrm{V}$ and azakauranes have appeared in their effects on the root growth. Compound V showed 19\% root elongation at $300 \mathrm{ppm}$, but azakauranes are considered to be very toxic to the root and only tiny roots appeared even in a low concentration of $30 \mathrm{ppm}$.

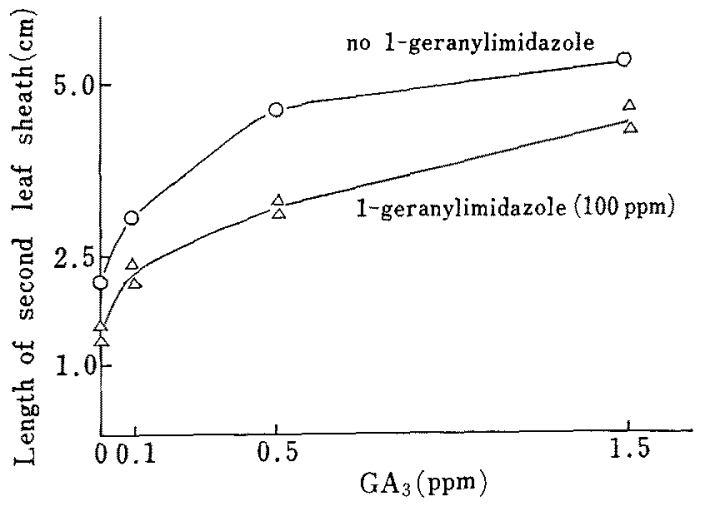

Fig. 3. Interaction between $\mathrm{GA}_{3}$ and 1-Geranylimidazole Observed in the Second Leaf Sheath Growth of Rice Seedlings.

Then, the antagonistic effect of gibberellin on the inhibition of second leaf sheath growth induced by 1-geranylimidazole (V) was examined. The inhibitory effect of $\mathrm{V}$ was not completely nullified by a high concentration (1.5 ppm) of $\mathrm{GA}_{3}$ as shown in Fig. 3. Downs and Cathey have reported that $\mathrm{GA}_{3}$ nullified the inhibition of stem growth induced by AMO-1618 in red kidney bean plant. ${ }^{8)}$ These facts suggest that compound $\mathrm{V}$ might inhibit other growth process besides inhibition of gibberellin biosynthesis.

\section{EXPERIMENTAL}

IR spectra were obtained by JASCO IR-G Spectro- 
photometer and UV spectra were measured in Hitachi EPS-3T Spectrophotometer. PMR spectra were recorded on a JEOL MH-100 Spectrometer with tetramethylsilane as internal standard.

MS and GC-MS were carried out using a JEOL D-100 Mass spectrometer fitted with a JEOL JGC-20K Gaschromatograph.

\section{Syntheses of geraniol derivatives}

To a suspension of $1 \mathrm{mmol}$ of $\mathrm{NaH}$ in $0.5 \mathrm{ml}$ of dry DMF in an ice bath was added $1 \mathrm{mmol}$ of a phenol or an amine in $1 \mathrm{ml}$ of dry DMF with vigorous stirring. Geranylbromide ( $1 \mathrm{mmol}$ ) in $0.5 \mathrm{ml}$ of dry DMF was added dropwise over a period of $10 \mathrm{~min}$ at $0^{\circ} \mathrm{C}$. The reaction mixture was stirred for $1 \mathrm{hr}$ at $0^{\circ} \mathrm{C}$. After continuous stirring for another $2 \sim 18 \mathrm{hr}$ at room temperature, the reaction mixture was poured onto ice water and extracted with $n$-pentane or ethyl acetate. The product was isolated by preparative thin-layer chromatography.

\section{Properties of geraniol derivatives}

O-Geranylsesamol (I), oil. MS $(\mathrm{m} / \mathrm{e}): 274\left(\mathrm{M}^{+}\right), 138$, 119, 117. IR $\nu_{\max }^{\mathrm{CHCl}_{3}} \mathrm{~cm}^{-1} 2760,940$ (methylenedioxy). UV $\lambda_{\max }^{\mathrm{MeOH}} \mathrm{nm}(\varepsilon): 296$ (1370). PMR $\left(\mathrm{CDCl}_{3}\right) \delta: 1.5$ $(3 \mathrm{H}, \mathrm{s}), 1.65(3 \mathrm{H}, \mathrm{s}), 1.68(3 \mathrm{H}, \mathrm{s}), 4.40(2 \mathrm{H}, \mathrm{d}, J=6)$, $5.04(1 \mathrm{H}, \mathrm{m}), 5.40(1 \mathrm{H}, \mathrm{t}, J=6), 5.80(2 \mathrm{H}, \mathrm{s})$.

Methyl o-geranyloxybenzoate (II), oil. $\operatorname{MS}(\mathrm{m} / \mathrm{e})$ : $288\left(\mathrm{M}^{+}\right)$, 152. $\mathrm{IR}_{-}^{\mathrm{max}} \mathrm{CHCl}_{3} \mathrm{~cm}^{-1}: 1730,1715,1600$. UV $\lambda_{\max }^{\mathrm{MeOH}} \mathrm{nm}(\varepsilon): 295$ (5000). PMR $\left(\mathrm{CDCl}_{3}\right) \delta: 1.57$ $(3 \mathrm{H}, \mathrm{s}), 1.64(3 \mathrm{H}, \mathrm{s}), 1.68(3 \mathrm{H}, \mathrm{s}), 3.80(3 \mathrm{H}, \mathrm{s}), 4.38$ $(2 \mathrm{H}, \mathrm{d}, J=6), 5.00(1 \mathrm{H}, \mathrm{m}), 5.42(1 \mathrm{H}, \mathrm{t}, J=6)$.

$N$-Geranyl, $N$-methylaniline (III), oil. MS $(\mathrm{m} / \mathrm{e})$ : $243\left(\mathrm{M}^{+}\right)$, 107. IR $\nu_{\mathrm{max}}^{\mathrm{CHCl}} \mathrm{cm}^{-1}: 1600,690$. UV $\lambda_{\mathrm{max}}^{\mathrm{MeOH}} \mathrm{nm}(s): 250$ (14450). PMR $\left(\mathrm{CDCl}_{8}\right) \delta: 1.55$ $(3 \mathrm{H}, \mathrm{s}), 1.63(3 \mathrm{H}, \mathrm{s}), 1.67(3 \mathrm{H}, \mathrm{s}), 2.82(3 \mathrm{H}, \mathrm{s}), 3.83$ $(2 \mathrm{H}, \mathrm{d}, J=6), 5.00(1 \mathrm{H}, \mathrm{m}), 5.15(1 \mathrm{H}, \mathrm{t}, J=6)$.

Methyl N-geranyl, N-methylanthraanilate (IV), oil. MS $(m / e): 301\left(\mathrm{M}^{+}\right), 286,244,232,165$. IR $\nu_{\mathrm{max}}^{\mathrm{CHO1} 3}$ $\mathrm{cm}^{-1}: 1720,1600$. UV $\lambda_{\max }^{\mathrm{MeOH}} \mathrm{nm}(\varepsilon): 270$ (5700), 338 (2260). PMR $\left(\mathrm{CDCl}_{3}\right): 1.58(3 \mathrm{H}, \mathrm{s}), 1.62(3 \mathrm{H}, \mathrm{s})$, $1.65(3 \mathrm{H}, \mathrm{s}), 2.72(3 \mathrm{H}, \mathrm{s}), 3.65(2 \mathrm{H}, \mathrm{d}, J=6), 3.80(3 \mathrm{H}, \mathrm{s})$, $5.04(1 \mathrm{H}, \mathrm{m}), 5.24(1 \mathrm{H}, \mathrm{t}, J=6)$.

1-Geranylimidazole (V), oil. MS $(\mathrm{m} / \mathrm{e}): 204\left(\mathrm{M}^{+}\right)$, 136. IR $\nu_{\max }^{\mathrm{CHCl}_{3}} \mathrm{~cm}^{-1}:$ 1665. PMR $\left(\mathrm{CDCl}_{3}\right): \delta 1.60$ $(3 \mathrm{H}, \mathrm{s}), 1.70(3 \mathrm{H}, \mathrm{s}), 1.75(3 \mathrm{H}, \mathrm{s}), 4.56(2 \mathrm{H}, \mathrm{d}, J=6)$, $5.10(1 \mathrm{H}, \mathrm{m}), 5.38(1 \mathrm{H}, \mathrm{t}, J=6), 6.90(1 \mathrm{H}, \mathrm{s}), 7.06(1 \mathrm{H}$, s), $7.48(1 \mathrm{H}, \mathrm{s})$.

1-Geranylbenzimidazole (VI), oil. MS (m/e): 254 $\left(\mathrm{M}^{+}\right), 186,118$. IR $\nu_{\mathrm{max}}^{\mathrm{CHCl} 3} \mathrm{~cm}^{-1}: 1665$. UV $\lambda_{\max }^{\mathrm{MeOH}}$ $\mathrm{nm}(\varepsilon): 250(6600), 255$ (6800), $266(4300), 275(4600)$, 281 (4600). PMR $\left(\mathrm{CDCl}_{3}\right): \delta 1.50(3 \mathrm{H}, \mathrm{s}), 1.60(3 \mathrm{H}, \mathrm{s})$,
$1.72(3 \mathrm{H}, \mathrm{s}), 4.68(2 \mathrm{H}, \mathrm{d}, J=7), 5.03(1 \mathrm{H}, \mathrm{m}), 5.36$ (1H, $\mathrm{t}, J=7$ ).

Methyl p-geranyloxybenzoate (VII), oil. MS (m/e): $288\left(\mathrm{M}^{+}\right)$, 152. IR $\nu_{\max }^{\mathrm{CHCl}_{3}} \mathrm{~cm}^{-1}: 1720,1710 . \mathrm{UV}$ $\lambda_{\text {max }}^{\mathrm{MeOH}} \mathrm{nm}(\varepsilon): 258(19800) . \quad$ PMR $\left(\mathrm{CDCl}_{\delta}\right) \delta 1.60$ $(3 \mathrm{H}, \mathrm{s}), 1.68(3 \mathrm{H}, \mathrm{s}), 1.75(3 \mathrm{H}, \mathrm{s}), 3.86(3 \mathrm{H}, \mathrm{s}), 4.60$ $(2 \mathrm{H}, \mathrm{d}, J=6), 5.10(1 \mathrm{H}, \mathrm{m}), 5.48(1 \mathrm{H}, \mathrm{t}, J=6), 6.92$ $(2 \mathrm{H}, \mathrm{d}, J=9.2), 8.00(2 \mathrm{H}, \mathrm{d}, J=9.2)$.

\section{Preparation of 17-nor-16-methylaminokaurane (VIII)}

A solution of $54.8 \mathrm{mg}(0.2 \mathrm{mmol})$ of 16 -nor-kauran-16one, $67.6 \mathrm{mg}$ ( $1.0 \mathrm{mmol})$ of methylamine hydrochloride and $25 \mathrm{mg}(0.8 \mathrm{mmol})$ of $\mathrm{NaBH}_{3} \mathrm{CN}$ in $2.4 \mathrm{ml}$ of absolute $\mathrm{MeOH}$ was stirred for $72 \mathrm{hr}$ at room temperature. The methanol was removed under reduced pressure, and the residue was dissolved in $8 \mathrm{ml}$ of $0.5 \mathrm{~N} \mathrm{HCl}$ and washed with two $10 \mathrm{ml}$ portions of ether. The aqueous layer was brought to $\mathrm{pH} 10$ with $6 \mathrm{~N} \mathrm{KOH}$, saturated with $\mathrm{NaCl}$, and extracted with three $20 \mathrm{ml}$ portions of ethyl acetate. The extracts were dried over $\mathrm{Na}_{2} \mathrm{SO}_{4}$ and evaporated to give $49 \mathrm{mg}$ of VIII as a colorless powder in $82 \%$ yield. $\operatorname{mp} 47.5 \sim 49^{\circ} \mathrm{C}$. IR $\nu_{\max }^{\mathrm{KBr}} \mathrm{cm}^{-1}$ : $3400,2770 . \quad \operatorname{PMR}\left(\mathrm{CDCl}_{\mathrm{s}}\right) \delta: 0.80(3 \mathrm{H}, \mathrm{s}), 0.84(3 \mathrm{H}, \mathrm{s})$, $1.02(3 \mathrm{H}, \mathrm{s}), 2.40(3 \mathrm{H}, \mathrm{s})$. MS $(m / e): 289\left(\mathrm{M}^{+}\right), 274$ $\left(\mathrm{M}^{+}-\mathrm{CH}_{3}\right), 258\left(\mathrm{M}^{+}-\mathrm{CH}_{3}-\mathrm{CH}_{4}\right), 233\left(\mathrm{M}^{+}-2 \times\right.$ $\mathrm{CH}_{3}-\mathrm{CH}_{4}$ ).

Preparation of 17-nor-16-dimethylaminokaurane (IX) IX was prepared by the same procedure used for the preparation of VIII in $89 \%$ yield as a colorless powder. $\operatorname{mp~} 103 \sim 106^{\circ} \mathrm{C}$. IR $\nu_{\max }^{\mathrm{KBr}} \mathrm{cm}^{-1}: 2810,2770$, $2720\left(-\mathrm{N}\left(\mathrm{CH}_{3}\right)_{2}\right)$. PMR $\left(\mathrm{CDCl}_{3}\right)$ \&: $0.80(3 \mathrm{H}, \mathrm{s}), 0.85$ $(3 \mathrm{H}, \mathrm{s}), 1.04(3 \mathrm{H}, \mathrm{s}), 2.20(6 \mathrm{H}, \mathrm{s}), \quad \mathrm{MS}(\mathrm{m} / \mathrm{e}): 303\left(\mathrm{M}^{+}\right)$, $288\left(\mathrm{M}^{+}-\mathrm{CH}_{3}\right)$.

\section{Preparation of 17-nor-16-dimethylaminokaurane methoio- dide $(\mathrm{X})$}

A solution of $50 \mathrm{mg}$ of IX and $0.2 \mathrm{ml}$ of methyl iodide in $2 \mathrm{ml}$ of methanol was heated under reflux for $2 \mathrm{hr}$. After evaporation of methanol the residue was crystallized from methanol to give $51 \mathrm{mg}$ of $\mathrm{X}$ as colorless prisms in $57 \%$ yield. $\mathrm{mp} 293 \sim 298^{\circ} \mathrm{C}$ (decomp.). PMR $\left(\mathrm{CDCl}_{3}\right) \delta: 0.80(3 \mathrm{H}, \mathrm{s}), 0.85(3 \mathrm{H}, \mathrm{s}), 1.00(3 \mathrm{H}$, s), $3.49(9 \mathrm{H}, \mathrm{s})$. $\mathrm{MS}(\mathrm{m} / \mathrm{e})$ : no $\mathrm{M}^{+}, 303\left(\mathrm{M}^{+}-\mathrm{CH}_{3} \mathrm{I}\right)$, $288\left(\mathrm{M}^{+}-\mathrm{CH}_{3} \mathrm{I}-\mathrm{CH}_{3}\right)$.

\section{Bioassay of microbial gibberellin biosynthesis}

Surface mycelium of $G$. fujikuroi grown for 3 days on potato-sucrose agar slant which is a kind gift from Prof. N. Takahashi was inoculated into $100 \mathrm{ml}$ of potato-glucose medium in $500 \mathrm{ml}$ Sakaguchi flask. After 3 days, vegetative cell cultures were transferred $\left(2 \mathrm{ml}\right.$ per $100 \mathrm{ml}$ fresh medium) and shaked at $30^{\circ} \mathrm{C}$ for 3 days. The mycelium was filtered through filter paper and washed with $40 \mathrm{ml}$ of $0.5 \% \mathrm{NaCl}$ solution 5 times. 
The washed mycelium $(0.3 \mathrm{~g})$ was soaked in $20 \mathrm{ml}$ of acetone for 2 days and repeated the same treatment twice. The acetone was evaporated and the residual solution was made alkaline and extracted with $5 \mathrm{ml}$ of EtOAc, and then acidified to $\mathrm{pH} 2$ and extracted with $5 \mathrm{ml}$ of EtOAc twice. No gibberellins were detected in the methyl esters of the acidic extract by GC.

A sample was added to the bottom of a test tube as EtOAC solution and the solvent was evaporated. The sample was then suspended in $0.5 \mathrm{ml}$ of $8 \%$ Tween 20 . To the test tube $0.3 \mathrm{~g}$ of the wet mycelium and $4.5 \mathrm{ml}$ of $0 \%$ ICI medium ${ }^{10)}$ were added and shaked at $30^{\circ} \mathrm{C}$ for 2 days. The mycelium was then filtered and the filtrate was made alkaline to $\mathrm{pH} 10$ and washed with $5 \mathrm{ml}$ of EtOAc to remove the neutral metabolites, and then acidified to $\mathrm{pH} 2$ and extracted with $5 \mathrm{ml}$ of EtOAc twice.

The acidic extract was concentrated and methylated with diazomethane. The methyl esters of the acidic metabolites were analyzed by GC: $3 \% \mathrm{OV}-1$ on Gas-chrom Q (80 100 mesh), $1 \mathrm{~m}$, carrier; $0.8 \mathrm{~kg} / \mathrm{cm}^{2}$ of $\mathrm{N}_{2}$, column temp. $215^{\circ} \mathrm{C}$.

The acidic metabolites produced in the control suspension were subjected to GC-MS analysis and the major peaks were identified as the methyl esters of $\mathrm{GA}_{7}$, diacid, $\mathrm{GA}_{13}$ and $\mathrm{GA}_{3}$ by comparison with the mass spectra of authentic compounds. ${ }^{9}$ )

\section{Rice seedling test}

Ten rice seeds (Oryza sativa L. normal cv., Kinmaze) just after germination were transferred into a sample tube $(7 \times 3.2 \mathrm{~cm})$, to which $1 \mathrm{ml}$ of distilled water containing a finite amount of a test sample was added. The sample tube was covered with a polyethylene cap and kept at $30^{\circ} \mathrm{C}$ in $12 \mathrm{hr}$ light condition.

After 6 days, the lengths of second leaf sheath and root were measured.

\section{REFERENCES}

1) K. Wada and T. Ishida, Kagaku To Seibutsu, 14, 748 (1976).

2) T. Ohta, R. J. Kuhr and W. S. Bowers, J. Agric. Food Chem., 25, 478 (1977).

3) T. Ishida and K. Wada, J. Chem. Soc. Chem. Commun., $1977,337$.

4) C. D. Upper and C. A. West, J. Biol. Chem., 242, 3285 (1977).

5) H. M. Cathey, Ann. Rev. Plant Physiol., 15, 271 (1964).

6) J. R. Bearder and V. M. Sponsel, Biochem. Soc. Trans., 5, 569 (1977).

7) R. F. Borch, M. D. Bernstein and H. Dupont Durst, J. Am. Chem. Soc., 93, 2897 (1971).

8) R. J. Downs and H. M. Cathey, Bot. Gaz., 121, 233 (1960).

9) N. Takahashi, "Gibberellins," ed. by S. Tamura, University of Tokyo Press, 1969, chapter 3; J. R. Beader and J. MacMillan, Phytochemistry, 12, 2655 (1973).

10) T. A. Geissman, A. J. Verbiscar, B. O. Phinney and G. Cragg, ibid., 5, 933 (1966). 